\title{
Front Matter: Volume 7968
}

, "Front Matter: Volume 7968," Proc. SPIE 7968, Medical Imaging 2011: Últrasonic Imaging, Tomography, and Therapy, 796801 (28 April 2011); doi: 10.1117/12.892634

SPIE Event: SPIE Medical Imaging, 2011, Lake Buena Vista (Orlando), Florida, SPIE. United States 


\title{
PROGRESS IN BIOMEDICAL OPTICS AND IMAGING
}

Vol. 12, No. 37

\section{Medical Imaging 2011}

\section{Ultrasonic Imaging, Tomography, and Therapy}

\author{
Jan D'hooge \\ Marvin M. Doyley \\ Editors
}

13-14 February 2011

Lake Buena Vista, Florida, United States

Sponsored by

SPIE

Cosponsored by

Dynasil Corporation/RMD Research (United States) - AAPM-American Association of Physicists in Medicine (United States) - DQE Instruments, Inc. (Canada) • Ocean Thin Films, Inc. (United States) - CREOL-The College of Optics and Photonics, Univ. of Central Florida (United States) VIDA Diagnostics, Inc. (United States)

Cooperating Organizations

APS-American Physiological Society (United States) • CARS—Computer Assisted Radiology and Surgery (Germany) • The Society for Imaging Science and Technology • Medical Image Perception Society (United States) • Radiological Society of North America (United States) Society for Imaging Informatics in Medicine (United States) - SMI-The Society for Molecular Imaging • The DICOM Standards Committee (United States)

Published by

SPIE

Volume 7968

Proceedings of SPIE, 1605-7422, v. 7968

SPIE is an international society advancing an interdisciplinary approach to the science and application of light. 
The papers included in this volume were part of the technical conference cited on the cover and title page. Papers were selected and subject to review by the editors and conference program committee. Some conference presentations may not be available for publication. The papers published in these proceedings reflect the work and thoughts of the authors and are published herein as submitted. The publisher is not responsible for the validity of the information or for any outcomes resulting from reliance thereon.

Please use the following format to cite material from this book:

Author(s), "Title of Paper," in Medical Imaging 2011: Ultrasonic Imaging, Tomography, and Therapy, edited by Jan D'hooge, Marvin M. Doyley, Proceedings of SPIE Vol. 7968 (SPIE, Bellingham, WA, 2011) Article CID Number.

ISSN 1605-7422

ISBN 9780819485106

Published by

SPIE

P.O. Box 10, Bellingham, Washington 98227-0010 USA

Telephone +1 3606763290 (Pacific Time) · Fax +1 3606471445

SPIE.org

Copyright (C) 2011, Society of Photo-Optical Instrumentation Engineers.

Copying of material in this book for internal or personal use, or for the internal or personal use of specific clients, beyond the fair use provisions granted by the U.S. Copyright Law is authorized by SPIE subject to payment of copying fees. The Transactional Reporting Service base fee for this volume is $\$ 18.00$ per article (or portion thereof), which should be paid directly to the Copyright Clearance Center (CCC), 222 Rosewood Drive, Danvers, MA 01923. Payment may also be made electronically through CCC Online at copyright.com. Other copying for republication, resale, advertising or promotion, or any form of systematic or multiple reproduction of any material in this book is prohibited except with permission in writing from the publisher. The CCC fee code is 1605$7422 / 11 / \$ 18.00$.

Printed in the United States of America.

Publication of record for individual papers is online in the SPIE Digital Library.

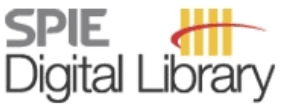

SPIEDigitallibrary.org

Paper Numbering: Proceedings of SPIE follow an e-First publication model, with papers published first online and then in print and on CD-ROM. Papers are published as they are submitted and meet publication criteria. A unique, consistent, permanent citation identifier (CID) number is assigned to each article at the time of the first publication. Utilization of CIDs allows articles to be fully citable as soon they are published online, and connects the same identifier to all online, print, and electronic versions of the publication. SPIE uses a six-digit CID article numbering system in which:

- The first four digits correspond to the SPIE volume number.

- The last two digits indicate publication order within the volume using a Base 36 numbering system employing both numerals and letters. These two-number sets start with 00, 01, 02, 03, 04, $05,06,07,08,09,0 A, 0 B \ldots 0 Z$, followed by 10-1Z, 20-2Z, etc.

The CID number appears on each page of the manuscript. The complete citation is used on the first page, and an abbreviated version on subsequent pages. Numbers in the index correspond to the last two digits of the six-digit CID number. 


\section{Contents}

ix Conference Committee

\section{SESSION 1 NEW DEVELOPMENTS IN ULTRASOUND TOMOGRAPHY}

796802 Double difference tomography for breast ultrasound sound speed imaging [7968-01] C. Li, N. Duric, O. Rama, A. Burger, L. Polin, N. Nechiporchik, Karmanos Cancer Institute (United States)

796803 Evaluation of the Bresenham algorithm for image reconstruction with ultrasound computer tomography [7968-02]

N. Spieß, M. Zapf, N. V. Ruiter, Karlsruhe Institute of Technology (Germany)

796804 Modification of Kirchhoff migration with variable sound speed and attenuation for tomographic imaging of the breast [7968-03]

S. Schmidt, O. Roy, C. Li, N. Duric, Karmanos Cancer Institute (United States); Z.-F. Huang, Wayne State Univ. (United States)

796805 Realization of an optimized 3D USCT [7968-04]

N. V. Ruiter, G. Göbel, L. Berger, M. Zapf, H. Gemmeke, Karlsruhe Institute of Technology (Germany)

796806 Robust array calibration using time delays with application to ultrasound tomography [7968-05]

O. Roy, Karmanos Cancer Institute (United States); I. Jovanović, Ecole Polytechnique Fédérale de Lausanne (Switzerland); N. Durić, Karmanos Cancer Institute (United States); L. Poulo, Analogic Corp. (United States); M. Vetterli, Ecole Polytechnique Fédérale de Lausanne (Switzerland) and Univ. of California, Berkeley (United States)

\section{SESSION 2 NOVEL IMAGING DEVICES AND APPROACHES}

796807 The development of a combined b-mode, ARFI, and spectral Doppler ultrasound imaging system for investigating cardiovascular stiffness and hemodynamics [7968-06] J. R. Doherty, D. M. Dumont, Duke Univ. (United States); G. E. Trahey, Duke Univ. (United States) and Duke Univ. Medical Ctr. (United States)

796808 Single pulse frequency compounding protocol for superharmonic imaging [7968-07] M. G. Danilouchkine, Erasmus Medical Ctr. (Netherlands) and Interuniversity Cardiology Institute of the Netherlands (Netherlands); P. L. M. J. van Neer, G. M. Matte, Erasmus Medical Ctr. (Netherlands); M. D. Verweij, Delft Univ. of Technology (Netherlands); N. de Jong, Erasmus Medical Ctr. (Netherlands) and Interuniversity Cardiology Institute of the Netherlands (Netherlands) 
796809 A novel imaging technique based on the spatial coherence of backscattered waves: demonstration in the presence of acoustical clutter [7968-08]

J. J. Dahl, Duke Univ. (United States); G. F. Pinton, Ecole Supérieure de Physique et de Chimie Industrielles (France); M. Lediju, G. E. Trahey, Duke Univ. (United States)

7968 OA Using high-power light emitting diodes for photoacoustic imaging [7968-09]

R. Skov Hansen, Institute of Sensors, Signals and Electrotechnics, Univ. of Southern Denmark (Denmark)

7968 OB Photoacoustic tomography with integrating fiber-based annular detectors [7968-10] H. Grün, H. Altmisdört, T. Berer, RECENDT GmbH (Austria); G. Paltauf, Karl-Franzens-Univ. Graz (Austria); G. Zangerl, M. Haltmeier, Univ. of Vienna (Austria); P. Burgholzer, RECENDT GmbH (Austria)

7968 OC Development of a c-scan photoacoutsic imaging probe for prostate cancer detection [7968-11]

K. S. Valluru, B. K. Chinni, Univ. of Rochester (United States); N. A. Rao, Rochester Institute of Technology (United States); S. Bhatt, V. S. Dogra, Univ. of Rochester (United States)

\section{SESSION 3 TISSUE CHARACTERIZATION AND MODELING}

7968 OD Support-vector-machines-based multidimensional signal classification for fetal activity characterization [7968-12]

S. Ribes, Institut de Recherche en Informatique de Toulouse, CNRS, Univ. of Toulouse (France); I. Voicu, J. M. Girault, INSERM, CNRS, Univ. of Tours (France); M. Fournier, F. Perrotin, CICT Univ. Hospital Tours (France); F. Tranquart, Bracco SA (Switzerland); D. Kouamé, Institut de Recherche en Informatique de Toulouse, CNRS, Univ. of Toulouse (France)

7968 OE An expectation maximization framework for an improved ultrasound-based tissue characterization [7968-13] M. Alessandrini, ARCES, Univ. di Bologna (Italy); S. Maggio, DEIS, Univ. di Bologna (Italy); J. Porée, CREATIS, CNRS, INSERM U630, Univ. de Lyon 1 (France); L. De Marchi, DEIS, Univ. di Bologna (Italy); N. Speciale, ARCES, Univ. di Bologna (Italy) and DEIS, Univ. di Bologna (Italy); E. Franceschini, Lab. de Mécanique et d'Acoustique, CNRS (France); O. Bernard, O. Basset, CREATIS, CNRS, INSERM U630, Univ. de Lyon 1 (France)

7968 OF Tissue classification using depth-dependent ultrasound time series analysis: in-vitro animal study [7968-43]

F. Imani, Queen's Univ. (Canada); M. Daoud, M. Moradi, P. Abolmaesumi, The Univ. of British Columbia (Canada); P. Mousavi, Queen's Univ. (Canada)

7968 OG Computer-aided tissue characterization using ultrasound-induced thermal effects: analytical formulation and in-vitro animal study [7968-15]

M. I. Daoud, The Univ. of British Columbia (Canada); P. Mousavi, F. Imani, Queen's Univ. (Canada); R. Rohling, P. Abolmaesumi, The Univ. of British Columbia (Canada)

$7968 \mathrm{OH}$ Three-dimensional computer simulation of high-frequency ultrasound imaging of healthy and cancerous murine liver tissues [7968-16]

M. I. Daoud, J. C. Lacefield, Robarts Research Institute (Canada) and The Univ. of Western Ontario (Canada) 
7968 ol Automatic detection and estimation of biparietal diameter from fetal ultrasonography [7968-17]

P. Annangi, K. Banerjee Krishnan, J. Banerjee, GE Global Research (India); M. Gupta, GE Healthcare (India); U. Patil, GE Global Research (India)

$79680 \mathrm{~J} \quad$ A two-dimensional locally regularized strain estimation technique: preliminary clinical results for the assessment of benign and malignant breast lesions [7968-18] E. Brusseau, V. Detti, CREATIS-LRMN, CNRS, INSERM U630, Univ. Lyon 1 (France); A. Coulon, E. Maissiat, Hospices Civils de Lyon, Hôpital de la Croix-Rousse (France); N. Boublay, Hospices Civils de Lyon, Univ. Lyon 1 (France); Y. Berthezène, CREATIS-LRMN, CNRS, INSERM U630, Univ. Lyon 1 (France) and Hospices Civils de Lyon, Hôpital de la Croix-Rousse (France); J. Fromageau, N. Bush, J. Bamber, The Institute of Cancer Research (United Kingdom)

7968 OK Preliminary comparison between real-time in-vivo spectral and transverse oscillation velocity estimates [7968-19]

M. M. Pedersen, Rigshospitalet (Denmark); M. J. Pihl, Technical Univ. of Denmark (Denmark); P. Haugaard, B-K Medical A/S (Denmark); J. M. Hansen, Technical Univ. of Denmark (Denmark); K. Lindskov Hansen, M. Bachmann Nielsen, Rigshospitalet (Denmark); J. A. Jensen, Technical Univ. of Denmark (Denmark)

$7968 \mathrm{OL} 2 \mathrm{D} / 3 \mathrm{D}$ image fusion of $\mathrm{x}$-ray mammograms with speed of sound images: evaluation and visualization [7968-20]

T. Hopp, J. Bonn, N. V. Ruiter, Karlsruhe Institute of Technology (Germany); M. Sak, N. Duric, Karmanos Cancer Institute (United States)

7968 OM Breast imaging with ultrasound tomography: update on a comparative study with MR [7968-21]

B. Ranger, P. Littrup, N. Duric, C. Li, S. Schmidt, O. Rama, L. Bey-Knight, Karmanos Cancer Institute, Wayne State Univ. (United States)

7968 ON Relationship between breast sound speed and mammographic percent density [7968-22] M. Sak, N. Duric, Karmanos Cancer Institute, Wayne State Univ. (United States); N. Boyd, Princess Margaret Hospital (Canada); P. Littrup, L. Myc, M. Faiz, C. Li, L. Bey-Knight, Karmanos Cancer Institute, Wayne State Univ. (United States)

\section{SESSION 5 MODELING FOR ULTRASOUND SYSTEM DESIGN}

$796800 \quad$ Finite element model of transducer array systems for 3D ultrasound computer tomography [7968-23]

B. Kohout, G. Göbel, N. V. Ruiter, Karlsruhe Institute of Technology (Germany)

7968 OP Comparison of simulated and measured nonlinear ultrasound fields [7968-24]

Y. Du, Technical Univ. of Denmark (Denmark) and B-K Medical Aps (Denmark); H. Jensen, B-K Medical Aps (Denmark); J. A. Jensen, Technical Univ. of Denmark (Denmark)

$79680 Q \quad$ Fast k-space-based evaluation of imaging properties of ultrasound apertures [7968-25] M. Zapf, R. Dapp, M. Hardt, Karlsruhe Institute of Technology (Germany); P. A. Henning, Hochschule Karlsruhe Technik und Wirtschaft (Germany); N. V. Ruiter, Karlsruhe Institute of Technology (Germany) 
7968 OR Transmit beamforming techniques for suppressing grating lobes in large pitch ultrasonic phased arrays [7968-26]

Z. Torbatian, R. Adamson, M. Bance, J. A. Brown, Dalhousie Univ. (Canada)

7968 OS A practical, robust approach to high-resolution breast ultrasound tomography [7968-27] P. Huthwaite, F. Simonetti, Imperial College London (United Kingdom)

\section{SESSION 6 KEYNOTE AND ULTRASOUND GUIDED INTERVENTION}

7968 OT Ultrasound image guidance of cardiac interventions (Keynote Paper) [7968-28]

T. M. Peters, Robarts Research Institute (Canada) and Canadian Surgical Technologies and Advanced Robotics (Canada); D. F. Pace, Robarts Research Institute (Canada) and Kitware Inc. (United States); P. Lang, Robarts Research Institute (Canada); G. M. Guiraudon, Robarts Research Institute (Canada) and Canadian Surgical Technologies and Advanced Robotics (Canada); D. L. Jones, The Univ. of Western Ontario (Canada) and Canadian Surgical Technologies and Advanced Robotics (Canada); C. A. Linte, Robarts Research Institute (Canada) and Mayo Clinic (United States)

7968 OU Quantification of prostate deformation due to needle insertion during TRUS-guided biopsy: comparison of hand-held and mechanically stabilized systems [7968-29]

T. De Silva, J. Bax, A. Fenster, Robarts Research Institute (Canada) and The Univ. of Western Ontario (Canada); J. Samarabandu, The Univ. of Western Ontario (Canada); A. D. Ward, Robarts Research Institute (Canada)

7968 OV A hybrid surface/image-based approach to facilitate ultrasound/CT registration [7968-30] S. Billings, National Institutes of Health (United States) and The Johns Hopkins Univ. (United States); A. Kapoor, National Institutes of Health (United States); M. Keil, Fraunhofer-Institut für Graphische Datenverarbeitung (Germany); B. J. Wood, National Institutes of Health (United States); E. Boctor, The Johns Hopkins Univ. (United States)

7968 OW Calibration of 3D ultrasound to an electromagnetic tracking system [7968-31] A. Lang, The Johns Hopkins Univ. (United States); V. Parthasarathy, A. Jain, Philips Research North America (United States)

\section{SESSION 7 VASCULAR IMAGING AND ULTRASOUND BEAM FORMING}

7968 0X Experimental observation of super-resolution imaging in highly attenuative materials [7968-34]

T. Hutt, F. Simonetti, Imperial College London (United Kingdom)

7968 OY An object-oriented multi-threaded software beamformation toolbox [7968-35]

J. M. Hansen, Technical Univ. of Denmark (Denmark); M. C. Hemmsen, Technical Univ. of Denmark (Denmark) and BK Medical Aps (Denmark); J. A. Jensen, Technical Univ. of Denmark (Denmark)

$79680 Z$ Feasability of a ARFI/B-mode/Doppler system for real-time, freehand scanning of the cardiovascular system [7968-36]

D. M. Dumont, S.-Y. Lee, J. R. Doherty, Duke Univ. (United States); G. E. Trahey, Duke Univ. (United States) and Duke Univ. Medical Ctr. (United States) 
796810 Turbulence intensity in a region of interest $2 \mathrm{~cm}$ distal to the carotid bifurcation in a family of seven anthropomorphic flow phantoms [7968-37]

J. L. Powell, T. L. Poepping, The Univ. of Western Ontario (Canada)

796811 Left ventricular 2D flow pattern estimation by combining speckle tracking with NavierStokes-based regularization in an iterative way [7968-38]

H. Gao, F. Kremer, H. F. Choi, J.-U. Voigt, P. Claus, J. D'hooge, Katholieke Univ. Leuven (Belgium)

796812 In-vivo imaging of breast cancer with ultrasound tomography: probing the tumor environment [7968-54]

N. Duric, P. Littrup, E. West, B. Ranger, C. Li, S. Schmidt, Karmanos Cancer Institute (United States)

\section{POSTER SESSION}

796813 Skeletonization approach for characterization of benign vs. malignant single thyroid nodules using 3D contrast enhanced ultrasound [7968-14]

F. Molinari, A. Mantovani, Politecnico di Torino (Italy); M. Deandrea, P. Limone, A. O. Ordine Mauriziano di Torino (Italy); R. Garberoglio, Fondazione Scientifica Mauriziana ONLUS (Italy);

J. S. Suri, Biomedical Technologies, Inc. (United States) and Idaho State Univ. (United States)

796814 A new direct pixel-based focusing method for medical ultrasound imaging: preliminary results [7968-32]

Y. Lee, C. Piao, T. Kim, J. H. Chang, T.-K. Song, Y. Yoo, Sogang Univ. (Korea, Republic of)

796815 The new efficient multi-beamforming method based on multiple-access register block on a post-fractional filtering architecture [7968-33]

J. Kang, G. Kim, C. Yoon, Y. Yoo, T.-K. Song, Sogang Univ. (Korea, Republic of)

796816 Impedance-controlled ultrasound probe [7968-39]

M. W. Gilbertson, B. W. Anthony, Massachusetts Institute of Technology (United States)

796817 Fast algorithm for respiratory motion correction in free-breathing contrast-enhanced ultrasound imaging [7968-40]

J. Zhang, M. Ding, F. Meng, Y. Ming, Huazhong Univ. of Science and Technology (China)

$796818 \quad$ Xampling in ultrasound imaging [7968-41]

N. Wagner, Technion-Israel Institute of Technology (Israel); Y. C. Eldar, Technion-Israel Institute of Technology (Israel) and Stanford Univ. (United States); A. Fever, G. Danin, Technion-Israel Institute of Technology (Israel); Z. Friedman, GE Healthcare (Israel)

796819 The causal lossy impulse response of a circular piston evaluated in the time and frequency domains for power law media [7968-42]

C. T. Johnson, R. J. McGough, Michigan State Univ. (United States)

7968 lA Bedside assistance in freehand ultrasonic diagnosis by real-time visual feedback of 3D scatter diagram of pulsatile tissue-motion [7968-44]

M. Fukuzawa, K. Kawata, N. Nakamori, Kyoto Institute of Technology (Japan); Y. Kitsunezuka, Saiseikai Hyogo-ken Hospital (Japan) 
7968 1B Interference-based speckle filter [7968-45]

F. M. Cardoso, Univ. de São Paulo (Brazil); M. M. S. Matsumoto, Instituto do Coração do Hospital das Clínicas (Brazil); S. S. Furuie, Univ. de São Paulo (Brazil)

7968 1C Pad-printed thick-film transducers for high-frequency and high-power applications [7968-46]

W. W. Wolny, Meggitt A/S (Denmark); J. A. Ketterling, Riverside Research Institute (United States); F. Levassort, INSERM U930, CNRS, Univ. of Tours (France); R. Lou-Moeller, Meggitt A/S (Denmark); E. Filoux, J. Mamou, Riverside Research Institute (United States); R. H. Silverman, Riverside Research Institute (United States) and Columbia Univ. Medical Ctr. (United States); M. Lethiecq, INSERM U930, CNRS, Univ. of Tours (France)

7968 ID Ultrasound elastography using regularized phase-zero cost function initialized with dynamic programming [7968-47]

S. Sefati, H. Rivaz, E. Boctor, G. Hager, The Johns Hopkins Univ. (United States)

7968 1E Improved detectability of hypoechoic regions with short-lag spatial coherence imaging: experimental validation (Cum Laude Poster Award) [7968-48]

M. Jakovljevic, J. J. Dahl, G. E. Trahey, Duke Univ. (United States)

7968 1G A user friendly system for ultrasound carotid intima-media thickness image interpretation [7968-50]

X. Zhu, Arizona State Univ. (United States); C. B. Kendall, R. T. Hurst, Mayo Clinic (United

States); J. Liang, Arizona State Univ. (United States)

$7968 \mathrm{1H}$ On the measurement of ultrasound transmission through a penetrable acoustic cone [7968-51]

P. Huthwaite, F. Simonetti, Imperial College London (United Kingdom)

796811 High-resolution imaging with a real-time synthetic aperture ultrasound system: a phantom study [7968-52]

L. Huang, Y. Labyed, Los Alamos National Lab. (United States); F. Simonetti, Imperial College London (United Kingdom); M. Williamson, R. Rosenberg, P. Heintz, D. Sandoval, The Univ. of New Mexico (United States)

7968 IJ Navigation with local sensors in handheld 3D ultrasound: initial in-vivo experience [7968-53] P. J. Stolka, X. L. Wang, G. D. Hager, The Johns Hopkins Univ. (United States); E. M. Boctor, The Johns Hopkins Univ. (United States) and Johns Hopkins Medical Institutions (United States)

Author Index 


\title{
Conference Committee
}

\author{
Symposium Chairs \\ Maryellen L. Giger, The University of Chicago (United States) \\ Joseph M. Reinhardt, The University of lowa (United States) \\ Conference Chairs \\ Jan D'hooge, Katholieke Universiteit Leuven (Belgium) \\ Marvin M. Doyley, University of Rochester (United States) \\ Program Committee \\ Jeffrey C. Bamber, University of London (United Kingdom) \\ Johan G. Bosch, Erasmus University Rotterdam (Netherlands) \\ Stanislav Y. Emelianov, The University of Texas at Austin (United States) \\ James F. Greenleaf, Mayo Clinic (United States) \\ Michael F. Insana, University of Illinois at Urbana-Champaign (United \\ States) \\ Jørgen A. Jensen, Technical University of Denmark (Denmark) \\ Stephen A. McAleavey, University of Rochester (United States) \\ K. Kirk Shung, The University of Southern California (United States) \\ Kai E. Thomenius, General Electric Company (United States) \\ William F. Walker, University of Virginia (United States)
}

\section{Session Chairs}

1 New Developments in Ultrasound Tomography

Kai E. Thomenius, General Electric Company (United States)

2 Novel Imaging Devices and Approaches

Johan G. Bosch, Erasmus University Rotterdam (Netherlands)

3 Tissue Characterization and Modeling

Marvin M. Doyley, University of Rochester (United States)

$4 \quad$ Clinical Application of Novel Ultrasound Imaging Modalities

Johan G. Bosch, Erasmus University Rotterdam (Netherlands)

$5 \quad$ Modeling for Ultrasound System Design

Johan G. Bosch, Erasmus University Rotterdam (Netherlands) 
$6 \quad$ Keynote and Ultrasound Guided Intervention

Marvin M. Doyley, University of Rochester (United States)

$7 \quad$ Vascular Imaging and Ultrasound Beam Forming

Marvin M. Doyley, University of Rochester (United States) 